\title{
IMPLEMENTASI PELATIHAN PERSONAL DEVELOPMENT DALAM MENGEMBANGKAN KONSEP DIRI POSITIF PADA WARGA RUMAH PINTAR "BUNGA PADI" DI KABUPATEN MADIUN
}

\author{
Dahlia Novarianing Asri * \\ Dian Ratnaningtyas Afifah* \\ Diana Ariswanti Triningtyas *
}

\begin{abstract}
ABSTRAK
Penelitian ini bertujuan untuk mendapatkan deskripsi yang jelas mengenai (1) implementasi pelatihan personal development dalam mengembangkan konsep diri positif pada warga rumah pintar "Bunga Padi" di Kabupaten Madiun, dan (2) peranan pelatihan personal development dalam mengembangkan konsep diri positif pada warga rumah pintar "Bunga Padi" di Kabupaten Madiun.

Pendekatan penelitian yang digunakan adalah pendekatan penelitian kualitatif. Data dikumpulkan dengan menggunakan teknik observasi, wawancara, dan skala psikologi. Data-data yang telah dikumpulkan dianalisis melalui 3 alur kegiatan yang berlangsung secara bersamaan, yaitu (1) reduksi data, (2) penyajian data, dan (3) penarikan simpulan/verifikasi.

Berdasarkan hasil analisis data, diperoleh hasil sebagai berikut: (1) pelatihan personal development bagi warga Rumah Pintar "Bunga Padi" Kabupaten Madiun dapat diimplementasikan dengan lancar dan telah sesuai dengan prosedur standar serta tujuan yang telah ditetapkan. Pelatihan dilakukan melalui 5 tahap, yaitu: (a) penyampaian materi dan tugas tentang "Gambaran Diri", (b) penyampaian materi dan tugas tentang "Potensi Diri", (c) penyampaian materi dan tugas tentang "Pola Pikir", (d) penyampaian materi dan tugas tentang "Komitmen dan Cita-cita", (e) Evaluasi, dan (2) kegiatan pelatihan personal development dapat berperan dalam mengembangkan konsep diri positif pada warga Rumah Pintar "Bunga Padi" di Kabupaten Madiun. Berkembangnya konsep diri positif ini didasarkan pada 3 indikator, yaitu: (1) berkembangnya harapan positif, (2) berkembangnya afirmasi diri, dan (3) berkembangnya kemampuan menanggapi penilaian sosial yang terdapat pada diri peserta pelatihan.
\end{abstract}

Kata Kunci: pelatihan personal development, konsep diri positif

* Dahlia Novarianing Asri, Dian Ratnaningtyas Afifah dan Diana Ariswanti Triningtyas adalah Dosen Program Studi Bimbingan dan Konseling Fakultas Ilmu Pendidikan IKIP PGRI Madiun. 


\section{Pendahuluan}

Berawal dari ide dan pemikiran Ibu Negara, Ibu Ani Yudhoyono untuk turut berperan dalam mensejahterakan bangsa, Ibu Negara bersama Solidaritas Isteri Kabinet Indonesia Bersatu (SIKIB) menggagas Program Indonesia Pintar. Tujuan utama dari Program Indonesia Pintar adalah mewujudkan masyarakat berpengetahuan, masyarakat sejahtera (welfare society) dan masyarakat yang beradab (civilized society).

Salah satu kegiatan Indonesia Pintar adalah Program Rumah Pintar. Program ini merupakan pusat pemberdayaan masyarakat guna meningkatkan taraf hidup menuju masyarakat sejahtera. Rumah Pintar sebagai sarana pemberdayaan masyarakat dapat mewadahi berbagai kegiatan dimulai dari pendidikan anak usia dini, remaja, kaum perempuan juga kelompok lanjut usia. Diharapkan melalui Rumah Pintar terbangun masyarakat cerdas, inovatif, kreatif, mandiri yang sejahtera.

Tujuan dari kegiatan Rumah Pintar adalah: 1) Menciptakan masyarakat yang berpengetahuan; 2) Memberdayakan masyarakat; 3) Menjangkau masyarakat yang belum terjangkau layanan pendidikan; 4) Membantu pemerintah dalam memberikan pemerataan pendidikan; 5) Meningkatkan angka partisipasi masyarakat terhadap pendidikan; 6) Memberikan peluang usaha dan peluang kerja bagi masyarakat; 7) Meningkatkan taraf hidup masyarakat. Sasaran dari Program Rumah Pintar adalah kelompok masyarakat yang terdiri dari anak-anak, remaja, kaum perempuan dan lansia.

Rumah Pintar adalah "Rumah Pendidikan" untuk masyarakat yang berfungsi bagi: 1) anak-anak, untuk mengenalkan teknologi baru dan memberikan pelayanan pendidikan guna mengembangkan potensi yang dimiliki anak secara optimal sehingga dapat menjadi generasi yang berkualitas di masa mendatang; 2) wanita, untuk pemberdayaan kaum perempuan dengan segala potensi yang dimiliki melalui pelatihan dan pendidikan di sentra-sentra; 3) ekonomi keluarga, untuk mengembangkan keterampilan berbasis potensi lokal, diharapkan masyarakat mampu memenuhi kebutuhan ekonomi keluarga sehingga dapat meningkatkan kesejahteraan dan kemakmuran; 4) pengembangan sosial budaya, 
sebagai tempat untuk memacu kreativitas guna mempertahankan dan melestarikan budaya lokal, dan 5) pengembangan k.ewirausahaan, dalam rangka menumbuhkembangkan masyarakat untuk memiliki kemampuan dalam berwirausaha, termasuk di dalamnya menciptakan peluang kerja baru, meningkatkan pendapatan masyarakat sekitar sehingga tercipta masyarakat yang sejahtera.

Mengingat betapa pentingnya peranan Rumah Pintar bagi pencerdasan masyarakat, maka Program Rumah Pintar ini harus dikembangkan secara maksimal. Berkaitan dengan pemberdayaan Rumah Pintar sebagai rumah pendidikan alternatif, sangat penting diperhatikan adanya program pengembangan konsep diri positif bagi para peserta atau warga Rumah Pintar. Hal ini penting karena konsep diri yang dimiliki seseorang akan mendorong individu tersebut untuk melakukan hal-hal yang sesuai dengan pandangannya mengenai dirinya. Konsep diri merupakan landasan dalam menyesuaikan diri sehingga sangat penting dalam perkembangan diri seseorang. Dalam berinteraksi, setiap individu akan menerima tanggapan. Tanggapan yang diterima tersebut akan dijadikan cermin bagi individu untuk menilai dan memandang dirinya sendiri.

Konsep diri sangat berperan penting dalam dunia pendidikan mengingat proses pendidikan lebih sering menekankan pada ranah kognitif, padahal proses pendidikan secara keseluruhan menyangkut semua ranah, baik ranah afeksi maupun psikomotor. Sama halnya dengan pendidikan di rumah pintar. Warga rumah pintar memiliki karakteristik dengan latar belakang pendidikan yang minim, dan sosial ekonomi yang berbeda-beda. Sehubungan dengan hal itu maka perlu ada program-program pelatihan untuk mengembangkan konsep diri positif warga Rumah Pintar agar tidak merasa tertinggal atau dibedakan dengan masyarakat pada umumnya.

Salah satu bentuk pelatihan yang cocok untuk mengembangkan konsep diri para peserta Rumah Pintar adalah bentuk pelatihan personal development. Secara akseleratif, bentuk pelatihan personal development ini dipandang mampu mengembangkan konsep diri positif para peserta Rumah Pintar dalam satu siklus paket pembelajaran Rumah Pintar. 
Personal development atau pengembangan diri adalah suatu kegiatan individu dalam memahami dirinya sendiri, mengembangkan dan mengekspresikan diri sesuai dengan bakat, potensi, hasrat dan cita-cita di masa depan.

Berdasarkan UU Nomor 20 Tahun 2003 tentang Sisdiknas pasal 12 ayat (1b) tentang pelayanan pendidikan sesuai bakat, minat, dan kemampuan, pengembangan diri merupakan kegiatan pendidikan di luar mata pelajaran sebagai bagian integral dari kurikulum sekolah/madrasah. Kegiatan pengembangan diri merupakan upaya pembentukan watak dan kepribadian individu yang dilakukan melalui kegiatan pelayanan konseling berkenaan dengan masalah pribadi dan kehidupan sosial, kegiatan belajar, dan pengembangan karir, serta kegiatan ekstra kurikuler.

Dalam menunjang pendidikan, pengembangan diri bertujuan untuk mengembangkan: 1) bakat, 2) minat, 3) kreativitas, 4) kompetensi dan kebiasaan dalam kehidupan, 5) kemampuan kehidupan beragama, 6) kemampuan sosial, 7) kemampuan belajar, 8) kemampuan pemecahan masalah, dan 9) kemandirian.

Personal development atau pengembangan diri dapat terhambat karena beberapa faktor, baik faktor yang berasal dari diri sendiri maupun faktor yang berasal dari lingkungan (Eisya, 2011). Faktor-faktor penghambat yang berasal dari diri sendiri: a) Individu tidak memiliki tujuan hidup yang jelas; b) Individu kurang memiliki motivasi; c) Individu takut dalam menerima kenyataan karena memiliki kelemahan/kekurangan; d) Individu merasa tidak memiliki tantangan dan ketidakmampuan; e) Individu merasa tidak berharga.

Faktor-faktor penghambat yang berasal dari lingkungan: a) Sistem yang dianut di lingkungan, seperti pendidikan, pekerjaan, tempat tinggal; dan b) Kebiasaan, atau tradisi yang terjadi dalam lingkungan kebudayaan.

Materi Personal Development mengadaptasi dari penelitian Iin Tri Rahayu (2004) yang meliputi:

a. Gambaran diri dan memahami diri sendiri

Memberikan penjelasan tentang pengertian gambaran diri dan hubungan gambaran diri dengan penghargaan diri dan cota-cita. 
b. Potensi diri

Memberikan pemahaman kepada peserta mengenai potensi diri baik kekuatan maupun kelemahan, serta apa yang bisa dilakukan dengan kelebihan dan kelemahan tersebut dan memberikan cara bagaimana menggali potensi diri secara fisik, kepribadian, dan moral etik.

c. Pola pikir

Menjelaskan pengertian pola pikir, membedakan pola pikir positif dan pola pikir negatif, serta menjelaskan hubungan pola pikir dengan tindakan.

d. Komitmen dan cita-cita

Menjelaskan pengertian komitmen, dan memberikan contoh tingkah laku sebagai bentuk komitmen diri, serta menjelaskan hubungan komitmen dengan pencapaian cita-cita.

Menurut Hurlock (2001), konsep diri adalah gambaran yang dimiliki orang tentang dirinya. Sedangkan Burn (dalam Leonard dan Supardi, 2010: 342) menjelaskan bahwa konsep diri adalah" gambaran campuran dari apa yang kita pikirkan, orang-orang berpendapat mengenai diri kita, dan seperti apa diri kita yang kita inginkan".

Konsep diri dapat diartikan sebagai penilaian dan perasaan seseorang terhadap dirinya, baik menyangkut aspek fisik, psikis, maupun sosial. Pajares dan Schunk (dalam Andriani, 2005: 60) menggambarkan konsep diri sebagai penilaian kognitif seseorang dari harapan-harapan, dan deskripsi seseorang mengenai dirinya sendiri. Lebih lanjut, Gage dan David (dalam Andriani, 2005: 124) mendefinisikan konsep diri sebagai totalitas persepsi yang dimiliki seseorang tentang dirinya sendiri, sikap terhadap dirinya, cara yang biasa digunakan untuk menggambarkan dirinya. Seifert dan Hoffnung (dalam Desmita, 2009: 77) mendefinisikan konsep diri sebagai suatu pemahaman mengenai diri atau ide tentang diri sendiri.

Menurut Calhoun dan Acocella (1990: 87) konsep diri positif digambarkan sebagai penerimaan diri seseorang yang lebih mengarahkan pada kerendahan hati dan kedermawanan, Individu dengan konsep diri yang positif dicirikan dengan 
adanya kemampuan dalam mengatasi masalah, dan dapat memahami dan menerima fakta yang sangat beragam tentang dirinya, serta dapat menerima dirinya sendiri dengan apa adanya.

Berdasarkan uraian di atas, dapat disimpulkan bahwa konsep diri positif adalah gambaran dan penilaian seseorang terhadap dirinya sendiri, mampu memandang dirinya dari sudut pandang orang lain, serta memiliki kemampuan dalam mengatasi masalah.

Menurut Brooks dan Emmert (dalam Rakhmat, 1996: 56) kriteria konsep diri positif dicirikan dengan kemampuan pada diri individu untuk mengatasi masalah. Individu merasa sejajar dengan orang lain, adanya kesadaran bahwa tiap individu memiliki keberagaman perasaan, mampu mengembangkan diri, memiliki kesanggupan dalam mengungkapkan kelebihan maupun kelemahannya serta memiliki kemampuan untuk berusaha memperbaiki dari kelemahan yang dimilikinya.

Menurut Bandono (2009) ciri-ciri pribadi dan perilaku yang memiliki konsep diri yang positif adalah: 1) merasa yakin atau percaya akan kemampuannya untuk mengatasi masalah yang dihadapinya; 2) merasa setara dengan orang lain; 3) dapat menerima pujian orang lain; 4) mampu memperbaiki dirinya apabila mengalami kegagalan; dan 5) mempunyai kepedulian terhadap kepentingan orang lain.

Menurut Lauer dan Handle (dalam Andriani, 2005), unsur-unsur konsep diri positif, yaitu meliputi kemampuan (ability), pencapaian prestasi yang lebih tinggi (more achievement) dan partisipasi sosial.

Berdasarkan uraian tersebut, peneliti akan mengadakan penelitian dengan judul "Implementasi Pelatihan Personal Development dalam Mengembangkan Konsep Diri Positif pada Warga Rumah Pintar "Bunga Padi" di Kabupaten Madiun”. Berdasarkan latar belakang masalah, dapat dirumuskan mengenai rumusan masalah penelitian ini: 1) Bagaimanakah implementasi pelatihan personal development dalam mengembangkan konsep diri positif pada warga rumah pintar "Bunga Padi" di Kabupaten Madiun? 2) Bagaimanakah pelatihan 
personal development dapat mengembangkan konsep diri positif pada warga rumah pintar "Bunga Padi” di Kabupaten Madiun?

Metode

Penelitian ini bertujuan untuk mendeskripsikan secara jelas tentang Implementasi pelatihan personal development dalam mengembangkan konsep diri positif pada warga rumah pimtar "Bunga Padi” di Kabupaten Madiun. Pendekatan yang dipergunakan adalah pendekatan kualitatif.

Penelitian ini dilakukan dengan lebih menekankan pada pengamatan peneliti terhadap interaksi antara instruktur pelatihan, tutor rumah pintar, dan warga rumah pintar dalam pelatihan personal development dalam mengembangkan konsep diri positif.

Penelitian dilaksanakan pada Rumah Pintar "Bunga Padi” yang terletak di Desa Balerejo, Kecamatan Balerejo, Kabupaten Madiun. Rumah Pintar "Bunga Padi" merupakan salah satu rumah pintar dari 8 rumah pintar yang ada di Kabupaten Madiun Jawa Timur.

Data dalam penelitian ini berupa sejumlah informasi yang berkaitan dengan implementasi pelatihan personal development dalam mengembangkan konsep diri positif pada warga rumah pimtar "Bunga Padi" di Kabupaten Madiun. Jenis sumber data yang dipergunakan dalam penelitian ini adalah sebagai berikut : 1) informan atau nara sumber. dalam penelitian ini digunakan 3 orang informan utama, yaitu seorang pengelola/pendamping, seorang tutor, dan 1 orang peserta/warga Rumah Pintar "Bunga Padi", Karena penelitian ini difokuskan pada implementasi pelatihan personal development dalam mengembangkan konsep diri positif pada warga rumah pintar "Bunga Padi" di Kabupaten Madiun, maka informan yang dipilih disesuaikan dengan orientasi penelitian tersebut. 2) Peristiwa atau aktivitas. Peristiwa atau aktivitas yang dipilih sebagai sumber data dalam penelitian ini adalah peristiwa implementasi pelatihan personal development dalam mengembangkan konsep diri positif pada warga rumah pintar "Bunga Padi" di Kabupaten Madiun. 3) Dokumen atau arsip. Dokumen atau arsip merupakan bahan tertulis yang bergayutan dengan suatu peristiwa atau aktivitas 
tertentu (Sutopo, 2002:54). Dalam penelitian ini, dokumen yang dipergunakan sebagai sumber data adalah dukumen-dokumen yang berkaitan dengan latar belakang warga rumah pintar "Bunga Padi" di Kabupaten Madiun.

Sesuai dengan karakteristik dan jenis data yang diperlukan, teknik pengumpulan data yang dipergunakan dalam penelitian ini meliputi dokumentasi, pengamatan atau observasi, wawancara dan skala psikologi.

Skala konsep diri positif dibuat dengan indikator konsep diri positif yang meliputi harapan positif, afirmasi diri, dan kemampuan menanggapi penilaian sosial.

Skala ini mempunyai empat pilihan jawaban yaitu SS (Sangat Sesuai), S (sesuai), TS (Tidak Sesuai), dan STS (Sangat Tidak Sesuai). Penilaian jawaban bergerak dari 1 sampai 4. Untuk butir favourable jawaban SS mendapatkan nilai 4, jawaban S mendapatkan nilai 3, jawaban TS mendapatkan nilai 2, dan jawaban STS mendapatkan nilai 1. Butir yang unfavourable, jawaban SS mendapat nilai 1, jawaban S mendapat nilai 2, jawaban TS mendapat nilai 3, dan jawaban STS mendapat nilai 4. Penyebaran butir untuk masing-masing item secara rinci dapat dilihat pada tabel berikut:

Tabel 1. Blue Print Konsep Diri Positif

\begin{tabular}{|c|l|l|l|c|}
\hline \multirow{2}{*}{ No } & \multicolumn{1}{|c|}{ Indikator } & \multicolumn{2}{c|}{ Distribusi butir item } & \multirow{2}{*}{ Jumlah } \\
\cline { 3 - 4 } & & Favourable & Unfavourable & \\
\hline 1 & Harapan positif & $1,7,13,19$ & $4,10,16$, & 7 \\
\hline 2 & Afirmasi diri & $2,8,14$ & $5,11,17,20$ & 7 \\
\hline 3 & $\begin{array}{l}\text { Kemampuan menanggapi } \\
\text { penilaian sosial }\end{array}$ & $3,9,15$ & $6,12,18$ & 6 \\
\hline \multicolumn{3}{|c|}{ Jumlah } & 20 \\
\hline
\end{tabular}

Analisis data terhadap data penelitian ini dilakukan dalam dua tahap, yaitu pada saat atau selama berlangsungnya pengumpulan data dan setelah pengumpulan data. Menurut Miles dan Huberman (1992:73-74), analisis data selama pengumpulan data dapat memberikan kesempatan kepada peneliti lapangan untuk memikirkan tentang data yang ada dan menyusun strategi untuk mengumpulkan data. Hal tersebut dapat menjadi koreksi yang sehat bagi hal 
terselubung yang tidak terlihat sebelumnya. Lagi pula, analisis data yang terus menerus memungkinkan adanya hasil laporan sementara yang merupakan suatu bagian dari sebagian besar kajian kebijakan dan evaluasi. Analisis data yang peneliti lakukan selama pengumpulan data ini juga dimaksudkan untuk mengembangkan dan menggali lebih jauh persoalan-persoalan yang mungkin muncul di lapangan.

Dengan mendasarkan pada pendapat Miles dan Huberman (1992:16-19), analisis data dalam penelitian ini dilakukan melalui 3 alur kegiatan yang berlangsung secara bersamaan, yaitu (1) reduksi data, (2) penyajian data, dan (3) penarikan simpulan/verifikasi.

Ketiga komponen analisis data di atas berjalan secara bersamaan pada waktu kegiatan pengumpulan data. Setelah peneliti menyusun catatan lapangan dengan lengkap, segera dilakukan kegiatan reduksi data, dan diteruskan dengan pengembangan bentuk susunan sajian data yang bersifat sementara. Berdasarkan sajian data tersebut selanjutnya peneliti menyusun simpulan/melakukan verifikasi. Simpulan ini masih bersifat sementara karena proses pengumpulan data masih tetap berlangsung. Begitu peneliti mendapatkan data-data baru dengan pemahaman baru, simpulan sementara tersebut akan diubah secara lebih tepat dan mantap.

Ketiga kegiatan analisis data tersebut, yaitu reduksi data, penyajian data, dan verifikasi/penarikan simpulan, prosesnya tidaklah sekali jadi, tetapi berinteraksi secara bolak balik, perkembangannya bersifat sekuensial dan interaktif. Proses interaksi tersebut dapat berlangsung antar komponennya maupun dengan proses pengumpulan data, dalam proses yang berbentuk siklus, bukan linear. Proses analisis data ini disebut dengan model analisis interaktif (Miles dan Huberman, 1992:19-20; Sutopo, 2002:95-96; Faisal, 2003:68-71). 
Siklus analisis data model interaktif tersebut dapat dilihat pada bagan berikut ini.

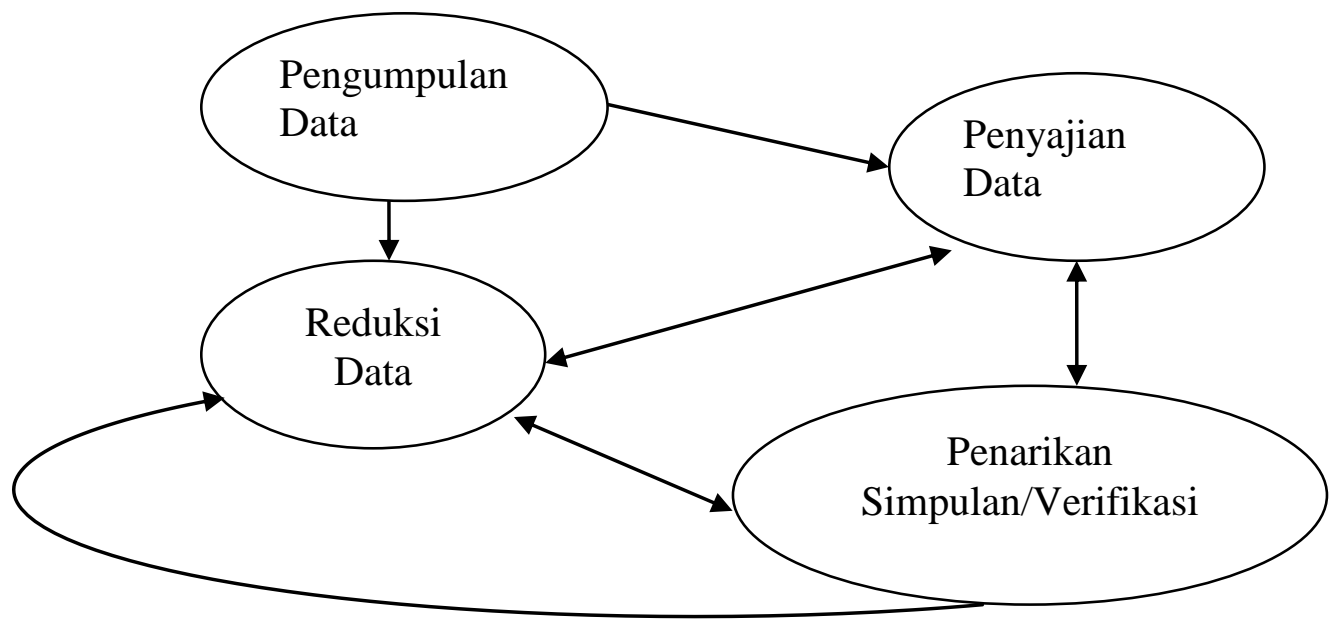

Gambar 1

Komponen-komponen Analisis Data Model Interaktif

Hasil

Berdasarkan hasil analisis data, diperoleh hasil sebagai berikut: (1) pelatihan personal development bagi warga Rumah Pintar "Bunga Padi” Kabupaten Madiun dapat diimplementasikan dengan lancar dan telah sesuai dengan prosedur standar serta tujuan yang telah ditetapkan. Pelatihan dilakukan melalui 5 tahap, yaitu: (a) penyampaian materi dan tugas tentang "GambaranDiri”, (b) penyampaian materi dan tugas tentang "Potensi Diri", (c) penyampaian materi dan tugas tentang "Pola Pikir", (d) penyampaian materi dan tugas tentang "Komitmen dan Cita-cita", (e) Evaluasi, dan (2) kegiatan pelatihan personal development dapat berperan dalam mengembangkan konsep diri positif pada warga Rumah Pintar "Bunga Padi" di Kabupaten Madiun. Berkembangnya konsep diri positif ini didasarkan pada 3 indikator, yaitu: (1) berkembangnya harapan positif, (2) berkembangnya afirmasi diri, dan (3) berkembangnya kemampuan menanggapi penilaian sosial yang terdapat pada diri peserta pelatihan.

Berdasarkan hasil penelitian tersebut, implikasi dari penelitian ini sebagai berikut. Pertama, mengingat pelatihan personal development sangat bermanfaat bagi pengembangan konsep diri positif warga rumah pintar, maka penelitian ini dapat dilaksanakan pada rumah pintar-rumah pintar yang lain, khususnya yang 
berada di Kabupaten Madiun, yang menurut data berjumlah 12 rumah pintar. Kedua, pelatihan personal development memerlukan persiapan yang matang. Tujuan pelatihan harus dososialisasikan kepada para tutor, pengelola, dan peserta pelatihan jauh-jauh hari sebelumnya agar mereka memiliki pemahaman yang sama terhadap tujuan diadakannya pelatihan. Materi pelatihan harus dikemas dalam bentuk buku yang dapat dipelajari oleh seluruh peserta di luar jam-jam pelatihan. Ketiga, pelatihan ini memerlukan instruktur yang memiliki latar belakang pendidikan di bidang psikologi, khususnya yang menguasai tentang personal development dan menguasai teknik-teknik pengukuran skala psikologi. Instruktur lebih diutamakan yang memiliki kemampuan memotivasi dan komunikasi verbal yang menarik, agar para peserta pelatihan selalu termotivasi untuk mengikuti seluruh kegiatan.

\section{DAFTAR PUSTAKA}

Andriani. 2005. Hubungan Minat Profesi Pendeta dan Konsep Diri dengan Prestasi Akademik Mahasiswa Sekolah Tinggi Theologi HKBP Pematang Siantar. Tesis. Yogyakarta: Universitas Gadjah Mada.

Bandono. 2009. Konsep Dasar dan Pengembangan Diri Secara Efektif. Diakses dari http://www.bandono.web.id.

Bogdan, Robert C. dan Steven J. Taylor. 1975. Introduction to Qualitative Research Method. New York: A Wiley Inscience Publication.

Calhoun, J.F., \& Acocella, J.R. 1990. Psichplogy of Adjustment and Human Relationship. New York: McGrawHill.

Eisya. 2011. Kepribadian dan Pengembangan Diri. Diakses dari http://www.eisya-personality.blogspot.com.

Faisal, Sanapiah. 2003."Pengumpulan dan Analisis Data dalam Penelitian Kualitatif", dalam Burhan Bungin (ed). Analisis Data Penelitian Kualitatif. Jakarta: Raja GrafindoPersada.

Hurlock, E.B. 2001. Psikologi Perkembangan: Suatu Pendekatan Sepanjang Rentang Kehidupan (terjemahan). Jakarta: Erlangga.

Rahayu, Iin Tri. 2004. Pengaruh Pelatihan Pengembangan Diri Terhdap Peningkatan Berpikir Positif dan Penurunan Kecemasan Berbicara Di Depan Umum. Tesis. Yogyakarta: Universitas Gadjah Mada.

Kirk, Jerome dan Marc L. Miller. 1986. Reliability and Validity in Qualitative Research Vol 1. Beverly Hills: Sage Publication.

Leonard dan Supardi. 2010. Pengaruh Konsep Diri, Sikap Siswa Pada Matematika, dan Kecemasan Sisea Terhadao Hasil Belajar Matematika. 
Cakrawala Pendidikan. Jurnal Ilmiah Pendidikan.November 2010, Th.XXIX, No.3.

Miles, Matthew B. dan A. Michael Huberman. 1992. Analisis Data Kualitatif (terj. Tjetjep Rohendi Rohidi). Jakarta: Universitas Indonesia.

Moleong, Lexy J. 2004. Metode Penelitian Kualitatif.Bandung: RemajaRosdakarya.

Patton, Michael Quinn. 1987. Qualitative Evaluation Methods. Beverly Hills: Sage Publications.

Rakhmat, J. 1996. Psikologi Komunikasi. Bandung: Remaja Rosdakarya.

Samarin, William J. 1988. Ilmu Bahasa Lapangan (terj. J.S. Badudu). Jakarta: Kanisius.

Singarimbun, Irawati. 1985. "Teknik Wawancara”, dalam Masri Singarimbun dan Sofian Effendi (ed). Metode Penelitian Survai. Jakarta: LP3ES.

Sutopo, H.B. 2002. Metode Penelitian Kualitatif, Dasar Teori dan Terapannya dalam Penelitian. Surakarta: Sebelas Maret University Press. 